Rev. Biol. Trop., 47(1-2): 217-223, 1999

www.ucr.ac.cr www.ots.ac.cr www.ots.duke.edu

\title{
Status of some populations of Mexican salamanders (Amphibia: Plethodontidae)
}

\author{
Gabriela Parra-Olea, Mario García-París and David B. Wake
}

Museum of Vertebrate Zoology, University of California, 3101 Valley Life Sciences Building, Berkeley, California 94720-3160, USA. Fax 5106438238. E-mail: wakelab@uclink4.berkeley.edu.

Received 8-I-1998. Corrected 7-XI-1998. Accepted 9-XI-1998.

\begin{abstract}
Populations of Mexican plethodontid salamanders have been surveyed non-systematically over the last 25 years. In light of many reports of disappearance of amphibians around the world, we checked for persistence of reported species at ten of these sites. All of the commoner species persist (we observed individuals representing a total of 30 species). While observed densities of many species of Mexican plethodontids are lower to much lower than was the case 20 to 25 years ago, evidence for recent extinctions, such as has been reported for amphibian taxa elsewhere, is equivocal or lacking. Habitat modification has contributed to difficulties in finding certain species.
\end{abstract}

Key words: Salamanders, amphibian declines, populations, Plethodontidae, Mexico.

Between 1971 and 1981 personnel from the Museum of Vertebrate Zoology (MVZ, University of California at Berkeley) conducted field research on Mexican plethodontid salamanders, and much information on species occurrences and distribution was accumulated (e.g., Wake and Lynch 1976, 1982; Lynch et al. 1977, 1983; Hanken 1983; Papenfuss et al. 1983; Papenfuss and Wake 1987; Wake 1987; Wake 1992; Lynch and Wake 1989; Wake and Johnson 1989; Wake et al. 1992; Darda 1994; Hanken and Wake 1994, 1998). The current decade has witnessed many reports of decline or disappearance of amphibian populations (Blaustein and Wake 1990; Pechmann and Wake 1997). Like many other tropical countries, Mexico has experienced rapid deforestation and land conversion, which negatively impact amphibian populations. But even in relatively undisturbed habitats elsewhere, amphibians have declined (e.g., Costa Rica, reviewed by Pounds et al. 1997). Evident declines of populations of plethodontid salamanders in Costa Rica (Parra et al., 1996; Wake unpublished data) raised questions concerning the status of Mexican plethodontid species, many once present in high density. While long term data are desireable, under present circumstances even positive observations of persistence are important (Blaustein et al. 1994). We made two study trips to Mexico during the spring and fall of 1997 to obtain specimens for laboratory studies, but incidentally were able to revisit many sites of previous investigations. We also report some earlier observations, made in late 1994. 


\section{MATERIALS AND METHODS}

We visited ten sites (Fig. 1) Our visits to sites three through nine took place during and immediately after the hurricane "Paulina" struck in October, 1997. Accordingly, it was very wet, and conditions everywhere were judged to be favorable for salamander activity. Most of the salamanders were located during the day by turning rocks and logs, breaking open rotten stumps and opening bromeliads. Salamanders were found during a few night excursions by searching on rocky walls and talus along road sides and searching on vegetation in the cloud forest. We are unable to quantify effort in relation to previous studies, but for most of the sites one collector (DBW) had participated in earlier searches and judged effort to be roughly equivalent.

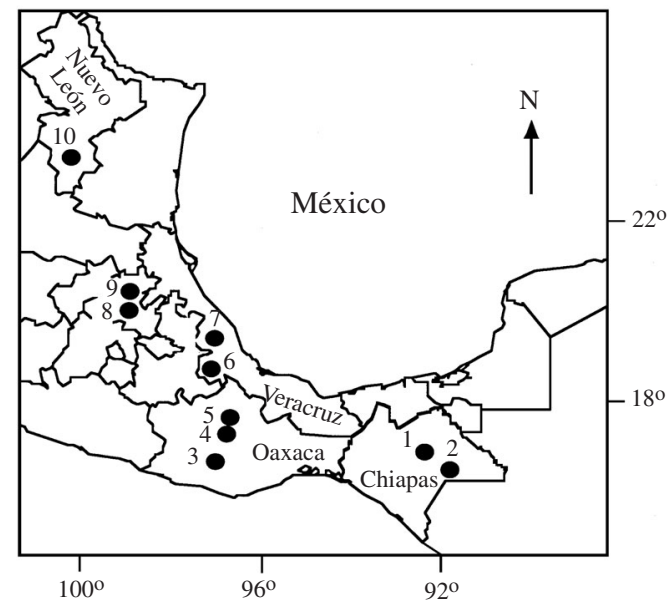

Fig. 1. Solid circles on the map of eastern Mexico mark localities mentioned in the text and tables. 1) Mountains west of San Cristóbal de las Casas, Chiapas, 2) vicinity of Lagos de Montebello, Chiapas, 3) Sierra Madre del Sur, south of Sola de Vega, Oaxaca, 4) Cerro San Felipe, north of Oaxaca, Oaxaca, 5) Sierra de Juárez, northern Oaxaca, 6) mountains south and west of Acultzingo on the border of Puebla and Veracruz, 7) northern and eastern slopes of Cofre de Perote, Veracruz, to vicinity of Xalapa, 8) vicinity of El Chico National Park, Hidalgo, 9) mountains between Zacualtipán and Tianguistenco, Hidalgo, and 10) slopes of Cerro Potosí and Pablillo, Nuevo León.
The relative abundance of salamanders at four of these sites for which data are most complete is presented in Table 1, together with data from previous years, obtained from field notes in the Museum of Vertebrate Zoology. The relative abundance of salamanders on each visit was estimated and coded using four categories (see Table). This procedure accounts for the lack of exact numbers when animals were extremely abundant and not collected in large quantities. Also, some species of Thorius discussed here were not described until recently, so data from all microsympatric species are combined and scored as "Unidentified" in the Table.

\section{RESULTS}

Site 1. The mountains west of San Cristóbal de las Casas, Chiapas, were visited briefly in mid-November 1994. The area is mostly covered by montane mixed pine forest on limestone rock, together with interspersed small cultivated fields and houses. Bolitoglossa hartwegi Wake and Brame 1969 and Bolitoglossa lincolni (Stuart 1943) are known to occur here, with the former species far commoner in the past (Wake and Lynch 1988). We spent one evening searching the sides of an abandoned road in a mainly pine forest and located nine specimens of $B$. hartwegi, the only species we observed.

Site 2. The area of the Lagos de Montebello, ca $1300 \mathrm{~m}$, Chiapas, was visited briefly in mid-November 1994. The region is mostly covered by pines, but the forest is badly degraded. Nevertheless, habitat for salamanders, including bromeliads, is present. We spent several hours during daylight but found only a single Bolitoglossa mexicana Duméril, Bibron and Duméril 1854, which has been collected here in the past. Nyctanolis pernix Elias and Wake 1983 was collected once in a cave near this site, but we did not search such a habitat. For these Chiapan sites (sites 1 and 2) the species we would expect to be the more common persist. 
Site 3. The northern-most ridge of the main Sierra Madre del Sur of Oaxaca is a part of the southern Oaxaca transect of Wake et al. (1992). The pine-oak habitat $(2100 \mathrm{~m})$ has been altered by logging activity since earlier visits. Three species are known here: Thorius minutissimus Taylor 1949, Pseudoeurycea cochranae (Taylor 1943), and Pseudoeurycea conanti Bogert 1967. The last species is the rarest (known from two specimens). We found only a single $T$. minutissimus. However, in the past abundances have varied erratically (Table 1).

Site 4. Cerro San Felipe, part of the northern Oaxaca transect of Wake et al. (1992; see also Wake 1987), has experienced extensive logging of its mainly pine forests, but habitat remains. We visited a summit area (ca 3000 - $3100 \mathrm{~m}$ ) where previous visits (Table 1) disclosed dense populations of Pseudoeurycea smithi (Taylor 1938) and Thorius narisovalis Taylor 1939; Pseudoeurycea unguidentis (Taylor 1941) and an undescribed species of Chiropterotriton also were present. We found only three specimens: one each of $T$. narisovalis and $P$. smithi, and an adult of an unknown species of Thorius.. Densities were greatly reduced relative to earlier trips, when hundreds of $P$. smithi were routinely encountered.

Site 5. The Sierra de Juárez is part of the northern Oaxaca transect of Wake et al. (1992), and three local areas were visited (Table 1). On a ridge overlooking Llano de las Flores (pine-oak forest; ca 2900 m) Thorius macdougalli Taylor 1949 was previously the most abundant species, but Thorius boreas Hanken and Wake 1994 was also well represented. A population assigned to $P$. smithi was present, but specimens were encountered infrequently. We found eight $T$. macdougalli and six $T$. boreas but no Pseudoeurycea. Further north, along the ridge connecting Cerro Pelón and Cerro Humo and on the immediate northern slope (ca 2900 m) we expected the same species of Thorius plus $T$. aureus Hanken and Wake 1994, an undescribed species of Pseudoeurycea, and Pseudoeurycea juarezi Regal 1966. We found the first four species, but only a total of 8 specimens, working both by day and by night. We found no $P$. juarezi, previously the species most reliably present in the area. Pseudoeurycea bellii (Gray 1850) has been taken in this area, but our teams have found very few specimens in the past so its absence is not surprising. The third area visited, along the north slope near La Esperanza, is cloud forest (ca. $2000 \mathrm{~m}$ ) where previous workers had found Thorius arboreus Hanken and Wake 1994, Nototriton adelos Papenfuss and Wake 1987, Pseudoeurycea saltator Lynch and Wake 1989, and an undescribed species of Chiropterotriton. While the first two species have been relatively uncommon, the latter two have been consistently present. Working by day and by night we found only the latter two species. Two $P$. saltator were active on vegetation at night, and an additional two specimens of that species plus seven Chiropterotriton were found in bromeliads (100 opened). The abundance of these two species in bromeliads is similar to findings in previous years.

Site 6. We visited two localities along the mountains south and west of Acultzingo on the border of Puebla and Veracruz. At Puerto del Aire a relatively rich fauna includes Thorius dubitus Taylor 1941, Thorius troglodytes Taylor 1941, Thorius magnipes Hanken and Wake 1998, Pseudoeurycea firscheini Shannon and Werler 1955, and an undescribed species of Chiropterotriton (Darda 1994). The forest is far more open, there are fewer large trees, and there are far fewer bromeliads than in the past. We found only four juvenile $T$. troglodytes. In past Thorius was abundant, but the other species were rare. The other locality, nearby on Cerro Teoxistle, produced but a single adult $T$. troglodytes, whereas in the past both T. troglodytes and Pseudoeurycea leprosa (Cope 1869) were common.

Site 7. The Veracruz transect of Wake et al. (1992) extends from the vicinity of Cofre de Perote to below Jalapa. At the highest point (ca. $3000 \mathrm{~m}$ ), a dense pine forest near Las Lajas microwave station, five species are 
TABLE 1

Species abundance at four selected Mexican localities.

Site 3. Puerto de la Cumbre, Sola de Vega (Oaxaca)

\begin{tabular}{llllllll}
\multicolumn{8}{c}{ Date of observation } \\
& $\begin{array}{l}11-71 \\
\text { (b) }\end{array}$ & $\begin{array}{l}11-74 \\
\text { (a) }\end{array}$ & $\begin{array}{l}8-75 \\
\text { (d) }\end{array}$ & $\begin{array}{l}2-76 \\
\text { (c) }\end{array}$ & $\begin{array}{l}7-76 \\
\text { (a) }\end{array}$ & $\begin{array}{l}10-81 \\
\text { (a) }\end{array}$ & $\begin{array}{l}10-97 \\
\text { (a) }\end{array}$ \\
T. minutissimus & 2 & 3 & 2 & 0 & 3 & 1 & 1 \\
$P$. cochranae & 2 & 2 & 2 & 0 & 1 & 1 & 0 \\
$P$. conanti & 0 & 1 & 0 & 0 & 0 & 1 & 0
\end{tabular}

Site 4. Cerro San Felipe (Oaxaca)

Date of observation

$\begin{array}{lllllllll} & \begin{array}{l}1-74 \\ \text { (b) }\end{array} & \begin{array}{l}8-74 \\ \text { (d) }\end{array} & \begin{array}{lll}11-74 \\ \text { (a) }\end{array} & \begin{array}{l}8-75 \\ \text { (e) }\end{array} & \begin{array}{l}2-76 \\ \text { (c) }\end{array} & \begin{array}{l}7-76 \\ \text { (a;c) }\end{array} & \begin{array}{l}10-81 \\ \text { (a) }\end{array} & \begin{array}{l}10-97 \\ \text { (a) }\end{array} \\ \text { P. smithi } & 2 & 3 & 3 & 3 & 3 & 3 & 3 & 1 \\ \text { T. pulmonaris } & * & 3 & 2 & * & 3 & 2 & 2 & 1 \\ \text { T. narisovalis } & * & 1 & 2 & * & 3 & 2 & 2 & 1 \\ \text { unidentified Thorius } & 1 & - & - & 2 & - & - & - & - \\ \text { P. unguidentis } & 0 & 2 & 0 & 3 & 0 & 2 & 0 & 0 \\ \text { Chiropterotriton sp. } 1 & 0 & 1 & 0 & 0 & 0 & 0 & 0\end{array}$

Site 5. Transect on Sierra de Juárez (Oaxaca)

\begin{tabular}{|c|c|c|c|c|c|c|c|c|}
\hline & $\begin{array}{l}1-74 \\
\text { (b) }\end{array}$ & $\begin{array}{l}8-74 \\
\text { (d) }\end{array}$ & $\begin{array}{l}11-74 \\
\text { (c) }\end{array}$ & $\begin{array}{l}8-75 \\
\text { (d) }\end{array}$ & $\begin{array}{l}2-76 \\
\text { (c) }\end{array}$ & $\begin{array}{l}7-78 \\
\text { (c) }\end{array}$ & $\begin{array}{l}10-81 \\
\text { (a) }\end{array}$ & $\begin{array}{l}10-97 \\
\text { (a) }\end{array}$ \\
\hline Pseudoeurycea sp. nov. & 0 & 0 & 1 & 2 & 1 & 1 & 2 & 1 \\
\hline P. bellii & 0 & 0 & 0 & 0 & 0 & 1 & 0 & 0 \\
\hline$P$. juarezi & 2 & 3 & 1 & 2 & 1 & 1 & 2 & 0 \\
\hline P. saltator & 1 & 2 & 1 & 1 & 0 & - & 0 & 1 \\
\hline P. smithi & 1 & 0 & 1 & 2 & 1 & 0 & 1 & 1 \\
\hline T. arboreus & $*$ & * & $*$ & $*$ & $*$ & $*$ & 1 & 0 \\
\hline T. aureus & $*$ & * & $*$ & $*$ & * & * & 0 & 1 \\
\hline T. boreas & * & * & $*$ & $*$ & $*$ & * & - & 2 \\
\hline T. macdougalli & $*$ & * & $*$ & $*$ & $*$ & * & - & 3 \\
\hline unidentified Thorius & 3 & 2 & 2 & 3 & 3 & 2 & - & - \\
\hline N. adelos & 0 & 1 & 0 & 0 & 1 & - & 0 & 0 \\
\hline Chiropterotriton sp. 2 & 2 & 1 & 2 & 2 & 2 & - & 1 & 2 \\
\hline
\end{tabular}

Site 7. Transect Cofre de Perote-Xalapa (Veracruz)

\begin{tabular}{|c|c|c|c|c|c|c|}
\hline & \multicolumn{6}{|c|}{ Date of observation } \\
\hline & $\begin{array}{l}1-74 \\
\text { (b) }\end{array}$ & $\begin{array}{l}11-74 \\
\text { (a) }\end{array}$ & $\begin{array}{l}7-76 \\
\text { (a) }\end{array}$ & $\begin{array}{l}7-79 \\
\text { (a) }\end{array}$ & $\begin{array}{l}10-81 \\
\text { (a) }\end{array}$ & $\begin{array}{l}10-97 \\
\text { (a) }\end{array}$ \\
\hline Pseudoeurvcea sp.1 & 0 & 0 & _ & 1 & 1 & 0 \\
\hline Pseudoeurycea sp. 2 & 0 & 0 & - & 0 & 1 & 2 \\
\hline P. bellii & 1 & 3 & 0 & 1 & 2 & 1 \\
\hline P. cephalica & 1 & 1 & 2 & 1 & 2 & 2 \\
\hline P. leprosa & 1 & 3 & 1 & 3 & 3 & 2 \\
\hline P. melanomolga & 0 & 0 & 0 & 3 & 3 & 1 \\
\hline C. cf. chiropterus & 2 & 1 & 3 & 2 & 2 & 2 \\
\hline C. lavae & 2 & 1 & - & 3 & 2 & 2 \\
\hline T. minydemus & 0 & 1 & - & 0 & 0 & 1 \\
\hline T. munificus & 0 & 0 & 2 & 0 & 0 & 2 \\
\hline
\end{tabular}

Abundance levels: 0 (absent), 1 (present, $n=1-5$ ), 2 (frequent, $n=6-30$ ), 3 (common, $n>30$ ). Data source: (a) D.B. Wake MVZ Field Notes; (b) J. Lynch MVZ Field Notes; (c) J. Hanken MVZ Field Notes; (d) T. Papenfuss MVZ Field Notes. Site numbers as in figure 1. Asterisks indicate species assignment uncertain, recorded here as unidentified Thorius. Dashes, other than in Thorius cells, indicate that proper habitat for those species was not searched on that visit, so the abundance of the species was unknown. 
known: Pseudoeurycea melanomolga (Taylor 1941), P. leprosa, P. cephalica (Cope 1865), an as yet undescribed species of Pseudoeurycea, and Chiropterotriton chiropterus (Cope 1863). The first have been abundant in road banks, especially during relatively dry periods (Table 1 ). We found 16 $P$. leprosa, one $P$. melanomolga, and five Chiropterotriton, the taxa most frequently found in the past. At lower elevations we worked a remnant patch of pine-oak forest between Las Vigas and Cruz Blanca (2350 m) that has consistently produced $P$. leprosa, $P$. cephalica (both common), and a species previously assigned to $C$. chiropterus but considered by Darda (1994) to be an undescribed form. In addition, Thorius munificus Hanken and Wake 1998 has usually been present, occasionally in high densities. We found one $P$. leprosa and eight $P$. cephalica, but 16 Thorius (14 under the bark of a single $\log$ ). In July 1979, over 100 of each of these species were observed, but on another occasion when the habitat was dry, only three $P$. cephalica, one $P$. leprosa, and one Chiropterotriton were found. We also worked the La Joya area ( $c a 2100 \mathrm{~m}$ ), where six species are known: Pseudoeurycea bellii, $P$. cephalica, an undescribed species of Pseudoeurycea (different than the one at Las Lajas), Chiropterotriton lavae (Taylor 1942), C. cf. chiropterus, and Thorius minydemus Hanken and Wake 1998. Extensive logging and mining have modified the habitat. We found seven $C$. lavae in bromeliads (20 opened), one $C$. cf. chiropterus in a stump, and one $P$. bellii under rocks. In the past $P$. bellii has been more common, but the new species of Pseudoeurycea has been erratic in its presence and only one Thorius has been collected in many visits. A deep barranca located between Teocelo and Coatepec (ca. $1000 \mathrm{~m}$ ) in the past has produced Lineatriton lineola (Cope 1865), Parvimolge townsendi (Dunn 1922), Thorius pennatulus Cope 1869, and Pseudoeurycea praecellens (Rabb 1955). We failed to find salamanders, even though conditions seemed to be ideal and abundant surface cover objects were present. However, on at least one previous occasion we also failed to find any salamanders at this location.

Site 8. At El Chico National Park and immediate vicinity, the general vegetation changes dramatically from semiarid scrub land to oak, pine and fir forests. Forest cover is variable and open areas occur throughout, but we did not notice important changes in salamander habitat quality or availability. In the 1970's both Chiropterotriton multidentatus (Taylor 1938) and Chiropterotriton dimidiatus (Taylor 1939) occurred at unusually high densities and it was not uncommon to observe hundreds of both (on one visit 375 salamanders, not divided by species, were observed in a single morning). In the early 1970's C. multidentatus was the more common species, but later in the decade $C$. dimidiatus was encountered more frequently. By the early 1980's C. multidentatus had become rare and was not observed on some visits. A third species, P. cephalica, was always uncommon and infrequently seen. We spent several hours on a cold morning (ground frozen in exposed areas) and encountered only one specimen of $C$. dimidiatus (ca $2700 \mathrm{~m}$ elevation). Apparent densities are dramatically reduced relative to 25 years ago, although excellent habitat remains.

Site 9. A small patch of cloud forest lies on a ridge between Zacualtipán and Tianguistenco in central Hidalgo (1900 - 2000 $\mathrm{m})$. Salamanders have never been abundant here, but we found the three species known previously, Chiropterotriton terrestris (Taylor 1941), Chiropterotriton arboreus (Taylor 1941) and P. cephalica. We worked only long enough to find one of each of the three species. We searched ten bromeliads to find the single specimen of $C$. arboreus.

Site 10. The vicinity of Cerro Potosí, northern Nuevo León, is near the northernmost limit of tropical salamander distribution. The high $(3000 \mathrm{~m})$ pine-fir forest is decidedly non-tropical in aspect, and in the past dense populations of Chiropterotriton priscus Rabb 1956 have been found. In May, 1997, we 
found the species to be abundant under and in downed logs . At lower elevations, in semiopen oak habitat near the town of Pablillo, Pseudoeurycea galeanae (Taylor 1941) was known to occur, and we found three adults in the outer leaves of an agave.

We visited a number of additional sites during our three trips to Mexico, and in addition to the species mentioned above we also found the following species to be extant: T. schmidti Gehlbach 1959, T. lunaris Hanken and Wake 1998, T. minydemus, Bolitoglossa platydactyla (Gray 1831), and B. rufescens (Cope 1894).

\section{DISCUSSION}

While observed densities of many species of Mexican plethodontids are lower to much lower than was the case 20 to 25 years ago, evidence for recent extinctions, such as has been reported for amphibian taxa elsewhere, is equivocal or lacking. Habitat modification has contributed to difficulties in finding certain species. At several of the sites we failed to find species that have always been rare and frequently absent, so our failure is probably meaningless. For example, on Cerro San Felipe (Site 4) Chiropterotriton has been collected only once, and $P$. uniguidentis has been seen by MVZ teams only three times. Some species that we expected to find were absent. For example, $P$. juarezi was expected in the northern Oaxacan mountains. However, in the case of one missing species, Lineatriton lineola, it was found by GPO in May, 1998, so it persists despite the failure of our earlier attempts. Because our trips were of short duration the most likely reason for our failure to find them is seasonal variation in surface activity patterns. Our most significant findings are the positive observations of persistence of more than 30 species of plethodontid salamanders of previously undetermined status during a period of considerable concern for the global amphibian fauna.

\section{ACKNOWLEDGMENTS}

Studies in Mexico were financed in part by a grant from the US National Science Foundation (NSF BSR 90 19810), and by a summer research grant from the Center for Latin American Studies to GPO. We thank SEMARNAP and the authorities of the Municipio of Comaltepec, Oaxaca, for providing collecting permits. We also thank personnel associated with SERBO, A.C., in Oaxaca, for advice and discussion. We have used the field note collection of the Museum of Vertebrate Zoology to assemble Tables and we thank the authors of those notes. We also thank R. Bello, S. Deban, C. Haddad, S. Kuchta, M. Mahoney, F. F. Pedroche, K. Zamudio and anonymous reviewers for comments on the manuscript. GPO is sponsored by a fellowship from CONACyT.

\section{RESUMEN}

Poblaciones de varias especies de salamandras pletodóntidas en México han sido monitoreadas de manera no sistemática durante los últimos 25 años. Diez de éstas poblaciones fueran visitadas recientemente con el propósito de verificar la persistencia de las especies reportadas para dichas localidades. Nuestras observaciones confirman la persistencia local de más de 30 especies cuyo estatus era desconocido, aunque la frecuencia de observación de estas especies es en general menor que en fechas anteriores. Estas observaciones son particularmente relevantes dada la situación actual de preocupación por la disminución mundial de anfibios.

\section{REFERENCES}

Blaustein, A.R., \& D.B. Wake. 1990. Declining amphibian populations: a global phenomenon? Trends Ecol. Evol. 5: 203-204.

Blaustein, A.R., D.B. Wake \& W.P. Sousa. 1994. Amphibian declines: judging stability, persistence, and susceptibility of populations to local and global extinctions. Conserv. Biol. 8: 60-71.

Darda, D. 1994. Allozyme variation and morphological evolution among Mexican salamanders of the genus Chiropterotriton. Herpetologica 50: 164-187. 
Hanken, J. 1983. Genetic variation in a dwarfed lineage, the Mexican salamander genus Thorius (Amphibia: Plethodontidae): taxonomic, ecologic, and evolutionary implications. Copeia 1983: 1051-1073.

Hanken, J. \& D.B. Wake. 1994. Five new species of minute salamanders, genus Thorius (Caudata: Plethodontidae), from northern Oaxaca, Mexico. Copeia 1994: 573-590.

Hanken, J. \& D.B. Wake. 1998. The biology of tiny animals: systematics of the minute salamanders (Thorius: Plethodontidae) from Veracruz and Puebla, México, with descriptions of five new species. Copeia 1998: 312-345.

Lynch, J.F. \& D.B. Wake. 1989. Two new species of Pseudoeurycea (Amphibia: Caudata) from Oaxaca, Mexico. Contrib. Sci. Natur. Hist. Mus. Los Angeles County 411: 11-22.

Lynch, J.F., D.B. Wake \& S.Y. Yang. 1983. Genic and morphological differentiation in populations of the salamander genus Pseudoeurycea inhabiting the Transverse Volcanic Range of Mexico, with description of a new species. Copeia 1983: 884-894.

Lynch J.F., S.Y. Yang, \& T.J. Papenfuss. 1977. Studies of neotropical salamanders of the genus Pseudoeurycea, I. Systematics status of Pseudoeurycea unguidentis. Herpetologica 33: 46-52.

Papenfuss, T.J. \& D.B. Wake. 1987. Two new species of plethodontid salamanders (genus Nototriton) from Mexico. Acta Zool. Mex., nueva serie 21: 1-16.

Papenfuss, T.J., D.B. Wake \& K. Adler. 1983. Salamanders of the genus Bolitoglossa from the Sierra Madre del Sur of southern Mexico. J. Herpetol. 17: 295-307.

Parra, G., A.M. Welch \& S.J. McCauley. 1996. Evidence for Bolitoglossa subpalmata population decline on Cerro de la Muerte, Costa Rica. Abstracts 76th Annual Meeting, ASIH, p. 244.

Pechmann, J.H.K. \& D.B. Wake. 1997. Declines and disappearances of amphibian populations. In G. K.
Meffe \& C. R. Carroll \& Contributors, Principles of Conservation Biology, Second Edition, essay 5B, p. 135-137. Sinauer Associates, Sunderland, Massachusetts.

Pounds, J.A., M.P. Fogden, J.M. Savage \& G.C. Gorman. 1997. Tests of null models for amphibian declines on a tropical mountain. Conserv. Biol. 11:13071322.

Wake, D.B. 1987. Adaptive radiation of salamanders in Middle American cloud forests. Ann. Missouri Bot. Garden 74: 242-264.

Wake, D.B. 1992. An integrated approach to evolutionary studies of salamanders. In K. Adler (ed.). Herpetology: Current Research on the Biology of Amphibians and Reptiles. Proc. First World Congr. Herpetology, p. 163-177, Society for the Study of Amphibians and Reptiles.

Wake, D.B. \& J.D. Johnson. 1989. A new genus and species of plethodontid salamander from Chiapas, Mexico. Contrib. Sci. Natur. Hist. Mus. Los Angeles County 411: 1-10.

Wake, D.B., T.J. Papenfuss \& J.F. Lynch. 1992. Distribution of salamanders along elevational transects in Mexico and Guatemala. Tulane Stud. Zool. Bot., Suppl. Pub. 1: 303-319.

Wake, D.B. \& J.F. Lynch. 1976. The distribution, ecology, and evolutionary history of plethodontid salamanders in tropical America. Sci. Bull. Natur. Hist. Mus. Los Angeles County 25: $1-65$.

Wake, D.B. \& J.F. Lynch. 1982. Evolutionary relationships among Central American salamanders of the Bolitoglossa franklini group, with a description of a new species from Guatemala. Herpetologica 38: 257-272.

Wake, D.B. \& J.F. Lynch. 1988. The taxonomic status of Bolitoglossa resplendens (Amphibia: Caudata). Herpetologica 44: 105-108. 